\title{
The Framework of Competency Facilities Manager in Pre-Construction Hospital in Malaysia
}

\author{
Norsyazwana Jenuwa, Mohd Saidin Misnan, Mat Naim Abdullah
}

\begin{abstract}
This paper distinguishes was conducted on the importance of the facility mnager's competence for a complex construction project such as hospital construction. There is thus a need to study the competence of facilities managers at the level of hospital construction. Directly, the involvement of the facility manager at the construction stage can reduce the cost of operating the building. This paper study was carried out using two methods, namely questionnaire method and interview method. The study involved the construction of architects, engineers, quantity surveyors, public hospital staff and facilities managers directly involved in the construction of public hospitals in Malaysia. The data obtained were analyzed using descriptive analysis techniques, relative value index (RII) and analysis using SEM Smart PLS method. The findings found that almost all respondents felt that leadership factors, communication factors, operating and maintenance factors, human factors, property and property management factors, and business preparedness and business balance factors were factors influencing facility manager competence at the construction stage.
\end{abstract}

Keywords : Facilities management; Pre-construction; Facility Manager

\section{INTRODUCTION}

Facility management is closely related to building management. It is not only focused on operations management, but also on long-term user comfort. It is also very important in terms of cost of the building itself, starting with the construction of the building until it is delivered to the owner. The cost of operating a building is influenced by the building process including materials used, design designed to be safe for future use [1]. According to [2] facility management is a combination of technical and administrative actions aimed at keeping the components of the facility in good working condition.

Revised Manuscript Received on February 05, 2020.

* Correspondence Author

Norsyazwana Jenuwa *, Faculty of Built Environment \& Surveying, UTM Johor, MALAYSIA . Email: norsyazwanajenuwa@gmail.com

Mohd Saidin Misnan, Faculty of Built Environment \& Surveying, UTM Johor, MALAYSIA. Email: b-saidin@utm.my

Mat Naim Abdullah, Faculty of Built Environment \& Surveying, UTM Johor, MALAYSIA Email: matnaim@utm.my.

(C) The Authors. Published by Blue Eyes Intelligence Engineering and Sciences Publication (BEIESP). This is an open access article under the CC BY-NC-ND license (http://creativecommons.org/licenses/by-nc-nd/4.0/)
The ultimate goal of facility management is to minimize the costs of operating operations. The overall management of facilities includes the maintenance of building performance, maximizing staff safety, minimizing operating costs, mitigating environmental issues and reducing the risk of material damage.

According [3], facility management represents a career that encompasses a variety of roles through integration of people, places, processes and technologies. Figure 1.1 shows that the management of the facility can be characterized by four interrelated areas.

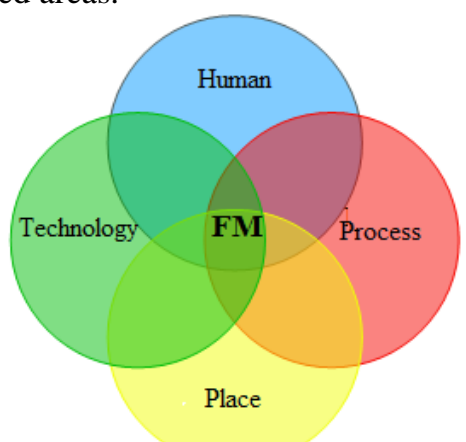

Figure 1.1: Facility Management (FM) - Human, Process, Technology and Place

As the manager of the facility must be someone who knows his role and his competent [3]. Competition of a facility manager is very important in a department. They are responsible for the entire building from the ground floor to the top so that users can enjoy the building, [4]. Facility manager duties include full responsibility for business premises, planning and provision of accommodation and support services to businesses and residents, building safety and maintenance, people management, time, cost and performance of buildings, etc. [5].

As such, this study will address the need to understand the competence of facility managers at the pre-construction stage and scope of this study is the public hospital in Malaysia

\section{PROBLEM STATEMENT}

According [3] has reviewed the future needs of the facility manager. The main issue identified in this study is competence. 
To meet the demands, challenges and opportunities for sustainable

development and practice, the facility manager must develop appropriate competencies as soon as possible. In preparation for the future, facility managers should carefully evaluate their effectiveness in relation to key issues that arise.

\section{LITERATURE REVIEW}

A literature search was coordinated to perceive concentrates related to competency of facility manager. The survey system included searching for distributed investigations from the past looks into databases using the keywords facilities management, facility manager, and pre-construction.

\section{DEFINITION COMPETENCY}

The various definitions available from previous studies indicate that competencies represent the many different characteristics, behaviors, and characteristics required for effective job performance. Personal competence is the individual or personality trait that people bring to their work, and is often used in the process of performance management, selection, and performance. Table 1.1 below shows previous studies on the definition of competency.

Table 1.1: Definition of competency

\begin{tabular}{|l|l|}
\hline Authors & \multicolumn{1}{c|}{ Definition } \\
\hline$[6]$ & $\begin{array}{l}\text { Define competence as knowledge, skills, abilities } \\
\text { or characteristics related to high performance in } \\
\text { the workplace, such as problem solving, thinking } \\
\text { analysis, or leadership. }\end{array}$ \\
\hline$[5]$ & $\begin{array}{l}\text { Competence is the ability to apply or apply } \\
\text { personal knowledge, skills, abilities, behaviors, } \\
\text { and characteristics to successfully perform critical } \\
\text { work tasks, specialized functions, or operate in } \\
\text { specific roles or positions. Efficiency, therefore, is } \\
\text { a fundamental characteristic of a person who } \\
\text { demonstrates how to behave or think which } \\
\text { covers a wide range of situations and lasts for a } \\
\text { long time. }\end{array}$ \\
\hline [3] $\begin{array}{l}\text { Competence is defined as the ability to perform } \\
\text { activities with the required standard of work, } \\
\text { using the right combination of knowledge, skills } \\
\text { and attitudes. All three of these aspects need to be } \\
\text { present in order to be effective in the workplace. } \\
\text { To increase competency, the facility manager } \\
\text { needs to improve not only knowledge but also } \\
\text { understanding of how that knowledge can be used } \\
\text { and skills in performing tasks effectively. }\end{array}$ \\
\hline The term competency refers to the knowledge, \\
skills, and behaviors needed to perform well and \\
compete with industry culture
\end{tabular}

Many definitions of terms of competence have increased over the past decade. The most popular definitions of competence include the accumulation of success factors needed to make important decisions in a particular job or role in a particular organizationl. Success factors are the combination of knowledge, skills, and abilities that are reflected in a particular set of behaviors, and are demonstrated by players who excel in their job or job role.

\section{THE ROLE AND FACILITY OF FACILITY MANAGERS}

Facility managers must be aware of their role and competence in maintaining buildings. Table 1.2 shows a description of the role and importance of a facility manager.

Table 1.2: The role and importance of the facility manager

\begin{tabular}{|l|l|}
\hline Authors & The role and importance of the facility manager \\
\hline$[7]$ & $\begin{array}{l}\text { Specifies that the facility manager is known as a } \\
\text { property manager and provides services for an } \\
\text { organization's operations support. }\end{array}$ \\
\hline$[6]$ & $\begin{array}{l}\text { A manager must think well and do his job well, and } \\
\text { he must clearly understand his role in his field. }\end{array}$ \\
\hline$[1]$ & $\begin{array}{l}\text { They can make a significant difference by using } \\
\text { sustainable management in their areas of } \\
\text { responsibility }\end{array}$ \\
\hline
\end{tabular}

Management of buildings and facilities is complex as buildings and facilities are a major part of fixed assets that are valuable to most organizations [8]. Pay attention to the complexity of the task, the efficiency of the facility manager. Generally, experienced and experienced facility managers can provide the services as needed by the organization or client, at a satisfactory level and ensure that all tasks are completed efficiently to provide excellent building performance.

\section{THE CONCEPTUAL FRAMEWORK OF COMPETENCY MANAGEMENT OF FACILITY MANAGERS}

Recent studies have presented a conceptual framework of studies that illustrates the relationship between elements of individual competence in managing facilities with key prestige indicators. Some areas are summarized following elements in a more easily understood form. The conceptual framework is based on the theory of the competence theory of the facility manager and the role of the facility manager. [3] The area of competence and itemization can influence the individual who manages the facility and, in turn, has an impact on the indicators of the pre-construction hospital facilities manager as can be clearly seen in Figure 1.2.

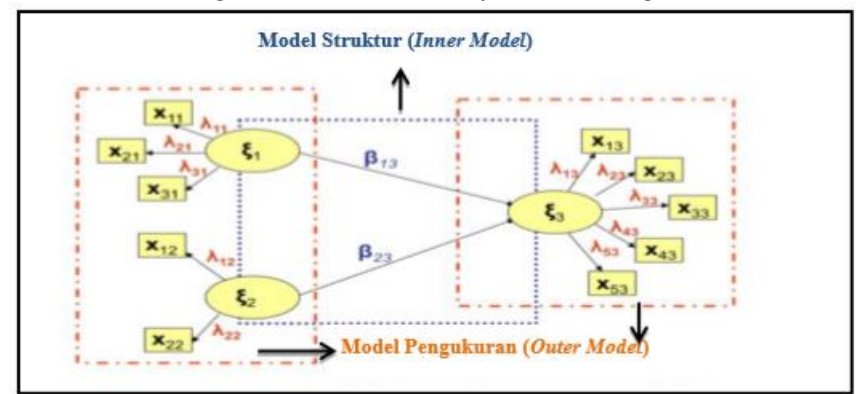

Figure 1.2: Sample structure model and measurement model. Source: [9]

Referring to Figure 4.10, the combination of measurement models and structural models leads to a complete structural equation model.

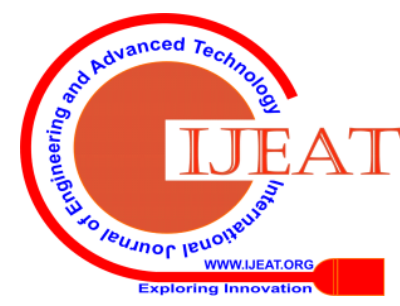


The model consists of two exogenous ( $\xi 1$ and $\xi 2)$ and one variable endogenous $(\xi 3)$. While latent variables (LVS) operate through X 12, X53, and indicator variables (manifest variables). The relationship between variables is measured by path coefficients. The bandwidth coefficients $\lambda$ in the measurement model are either determined by formative-weight variables or reflective-loading variables. While the coefficient of the path between the exogenous variable and the endogenous variable is labeled $\beta$. The first stage of model evaluation is to evaluate the measurement model. The second stage of the model evaluation is to evaluate the structural model. Model

evaluation analysis in SEM-PLS was performed using Smart PLS 2.0 M3 software [10] to test the proposed concept model.

\section{FINDINGS AND DISCUSSION}

In this study, the importance of all good practices in the development of maintenance culture was assessed using relative importance index (RII) analysis. The results of the RII calculation of the competency of the pre-construction facility manager are shown in Table 1.3.

Table 1.3: RII values of competency facility manager pre-construction

\begin{tabular}{|c|c|c|c|c|}
\hline $\begin{array}{c}\text { Competency Facility } \\
\text { Manager }\end{array}$ & Mean & $\begin{array}{l}\text { Std. } \\
\text { Deviation }\end{array}$ & RII & No \\
\hline $\begin{array}{l}\text { Communication With } \\
\text { Customers }\end{array}$ & 4.76 & 0.446 & 0.952 & 1 \\
\hline Communication skills & 4.72 & 0.499 & 0.944 & 2 \\
\hline $\begin{array}{l}\text { Communication to the } \\
\text { team }\end{array}$ & 4.69 & 0.526 & 0.943 & 3 \\
\hline Financial management & 4.69 & 0.486 & 0.939 & 4 \\
\hline Quality management & 4.65 & 0.508 & 0.931 & 5 \\
\hline Managing operating costs & 4.64 & 0.496 & 0.928 & 6 \\
\hline Resource management & 4.63 & 0.536 & 0.926 & 7 \\
\hline $\begin{array}{l}\text { Mechanical management } \\
\text { such as elevator services }\end{array}$ & 4.60 & 0.550 & 0.921 & 8 \\
\hline $\begin{array}{l}\text { Knowledge management } \\
\text { using technology }\end{array}$ & 4.59 & 0.538 & 0.918 & 9 \\
\hline $\begin{array}{l}\text { Management of building } \\
\text { maintenance }\end{array}$ & 4.59 & 0.516 & 0.918 & 10 \\
\hline $\begin{array}{l}\text { Management of heating, } \\
\text { ventilation and air } \\
\text { conditioning }\end{array}$ & 4.58 & 0.539 & 0.916 & 11 \\
\hline Strategy development & 4.58 & 0.554 & 0.915 & 12 \\
\hline Space management & 4.57 & 0.541 & 0.914 & 13 \\
\hline Decision maker & 4.56 & 0.528 & 0.911 & 14 \\
\hline $\begin{array}{l}\text { Time management and } \\
\text { work schedule of } \\
\text { employees }\end{array}$ & 4.56 & 0.528 & 0.911 & 15 \\
\hline Waste management & 4.55 & 0.570 & 0.911 & 16 \\
\hline
\end{tabular}

Referring to the results of the RII analysis as shown in Table 1.3 shows that the competency facility manager pre-construction was recorded RII values between 0.952 and 0.860 and the overall average value of RII was 0.912 . Thus, the competency facility manager pre-construction was recorded RII values is close to 1.0 [11]

Whereas the mean score value for each positive maintenance culture indicator was between 4.30-4.76. This indicates that all indicators of positive maintenance culture exceeded the mean score of 4.50 between agree and strongly agree range. Figure 1.3 shows a summary of the Structured Equation Modeling of the Smallest Partial Power Estimation (SEM-PLS) generated from the Smart PLS 2.0 M3 text output. 


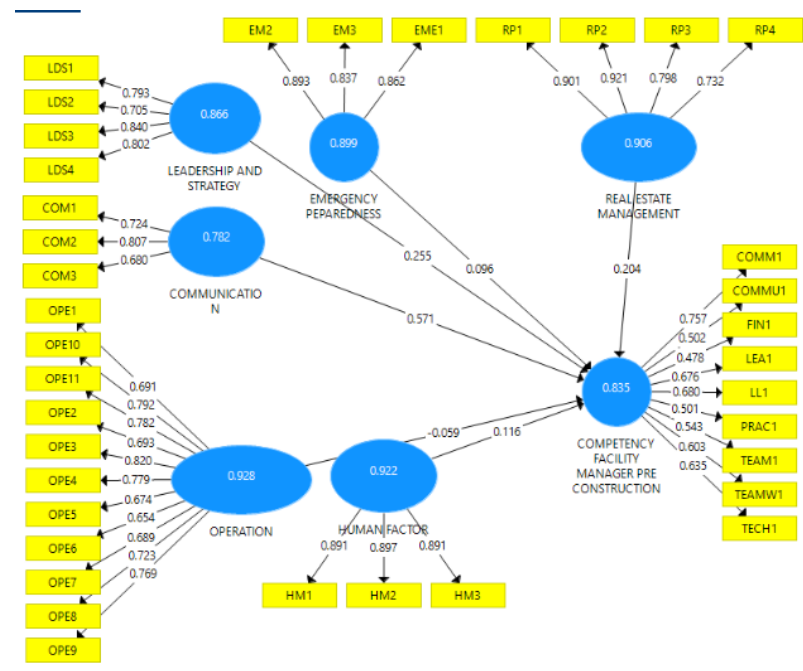

Figure 1.3: Measurement model analysis (SEM-PLS) analysis results

This shows that Composite Reliability is high where the indicator states that a value of $C$ greater than 0.80 or 0.90 is a correct assessment [12].

\section{CONCLUSION}

Through the findings discussed in detail, it was found that this study was successfully achieved through the analysis method discussed. This demonstrates the importance of pre-construction facility manager competencies that must be established. Among the most important competencies are leadership competency, communication, property and property management factors, and business preparedness and business and here we find that competency operation is not required as this competency needs to be in post-construction phase.

\section{ACKNOWLEDGMENT}

The author is a sponsor of MYbrain15 which sponsors all of this study's expenses

\section{REFERENCES}

1. Potkany M., Vetrakova M., and Babiakova M., (2015) "Facility Management and Its Importance in the Analysis of Building Life Cycle,.", Procedia Economics and Finance 26, 202 - 208.

2. Oladejo E. I., Umeh L. O and Egolum C. C; (2015), "The Challenges Of Healthcare Facilities Maintenance In Tertiary Hospitals In South East Nigeria", International Journal of Civil Engineering Construction and Estate Management, Vol.3, No.2, pp.1-6, June 2015

3. IFMA. (2015). Essentials of Facility Management Retrieved 27 November, 2015, from http://www.ifma.org/professionaldevelopment/new-to-facility-manag ementessentials- of-facility-management

4. Syahrul Nizam Kamaruzzaman and Nik Elyna Myeda (2017), Developing facilitiesmanagement (FM) competencies for Malaysia Reference from international practice, Journal of Facilities Management,Vol.16No.2,2018,pp.157-174

5. Meng X, (2014),"The role of facilities managers in sustainable practice in the UK and Ireland", Smart and Sustainable Built Environment, Vol. 3 Iss 1 pp. 23 - 34.

6. Nur Liyana Othman Mastura Jaafar , (2013),"Personal competency of selected women construction project managers in Malaysia", Journal of Engineering, Design and Technology, Vol. 11 Iss 3 pp. 276 - 287

7. Hamimah Adnan, Zafrul Fazry mohd Fauzi, Ismail Rahmat dan Azizan Supardi, (2012). Maintenance Management for Public Infrastructure for Malaysia Local Authorities. ARPN Journal of engineering and Applied Science, 7(11):1514-1522

8. Kamarazaly, M.A., Mbachu, J.,\& Phipps, R. (2013). Challenges faced by facilities managers in the Australasian universities. Journal of Facilities Management, 11(2), 136151.
9. Trinchera, L. dan Russolillo, G. (2010). On the Use of Structural Equation Models and PLS Path Modeling to Build Composite Indicators Working Paper. n. 30. Universatita Degli Study di Macerata, Dipartimento di Studi Sullo Sviluppo Economico, Macerata.

10. Ringle, C. M., Wende, S., dan Will, A. (2005). SmartPLS 2.0 M3 (beta). Hamburg, (http://www.smartpls.de)

11. Shardy Abdullah, Arman Abdul Razak, Mohd Hanizun Hanafi dan Mohd Najib Salleh. (2011). Managing Government Property Assets: The Main Issues from the Malaysian Perspective. Journal of Techno-Social. 3(1): 35-52.

12. Nunnally, J. C. dan Bernstein, I. H. (1994). Psychometric Theory. 3rd ed. New York: McGraw-Hill

\section{AUTHORS PROFILE}

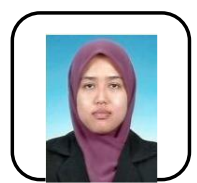

Norsyazwana Binti Jenuwa received B.Sc in Quantity Surveying, Universiti Teknologi Mara (2019), M.Sc in Intergrated Coastal Zones Management, Universiti Malaysia Terengganu (2011). She currently doing the Ph.D in Facility Management, UTM (2015-2020).

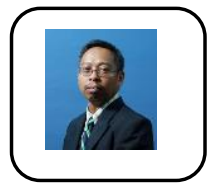

AP. Sr. Dr. Mohd. Saidin bin Misnan has a B.Sc in Quantity Surveying (UTM), M.Sc. in Project Management (USM), Ph.D. in Facilities Management, UTM. He is a Senior Lecturer, Department of Quantity Surveying, UTM.

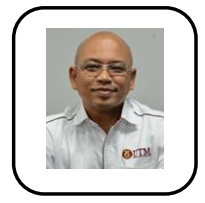

Mat Naim Bin Abdullah@ Mohd Asmoni has BSc. in Quantity Surveying (University of Glasgow Caledonian, United Kingdom), Master of Engineering in Construction (UTM), $\mathrm{PhD}$ in Facilities Management (UTM). He is a senior lecturer at the Department of Real Estate, Faculty of Geoinformation and Real Estate. 